\title{
Low-Moderate Doses of Nicotine Decreased mRNA of NGF and BDNF and Their Receptors at 30 Min in the Frontal Cortex and Hippocampus of ApoE-KO Mice
}

\author{
Mostofa Ruby ${ }^{\mathrm{a}}$, Kiyoshi Ameno ${ }^{\mathrm{b}}$, Mostofa Jamal ${ }^{\mathrm{b}, \mathrm{d}}$, Takanori Mikic, Naoko Tanaka ${ }^{\mathrm{b}}$, \\ Hiroshi Kinoshita ${ }^{\mathrm{b}}$, Yu Nakamura ${ }^{\mathrm{a}}$
}

\begin{abstract}
Background: Several studies have detected nicotine-associated increases in the mRNA and protein expression of NGF, BDNF and TrkA and TrkB receptors in multiple brain regions.

Methods: We investigated the acute effects of different doses of nicotine $(0.1,0.5$ and $1.0 \mathrm{mg} / \mathrm{kg})$ on the mRNA levels of NGF, BDNF, TrkA and TrkB in the frontal cortex and hippocampus of ApoE-knockout (ApoE-KO) and wild-type (WT) mice.

Results: The results demonstrated that in the frontal cortex and hippocampus, nicotine decreases NGF and BDNF mRNA levels in both ApoE-KO and WT mice. Nicotine also reduced TrkA in the frontal cortex and TrkB in both brain regions of WT mice, whereas no changes were observed in ApoE-KO mice. Interestingly, all of these effects were limited to low-intermediate doses $(0.1$ and 0.5 $\mathrm{mg} / \mathrm{kg}$ ) of nicotine, while $1.0 \mathrm{mg} / \mathrm{kg}$ of nicotine had no noticeable effect on the brain of either strain of mice. ApoE-KO mice showed a distinctly higher level of NGF mRNA expression versus the WT mice in both regions of the brain, whereas TrkA expression was lower only in the frontal cortex.
\end{abstract}

Conclusions: These findings suggest that acute nicotine causes a decrease in the mRNA levels of NGF, BDNF and their receptors in the frontal cortex and hippocampus of mice depending on nicotine doses. A high level of NGF mRNA was observed in the brain of ApoE-KO mice, suggesting a role of ApoE in the expressions of neurotrophins in the hippocampus.

Manuscript accepted for publication July 19, 2013

${ }^{a}$ Department of Neuropsychiatry, Faculty of Medicine, Kagawa University, 1750-1, Ikenobe, Miki, Kita, Kagawa 761-0793, Japan

${ }^{\mathrm{b}}$ Department of Forensic Medicine, Faculty of Medicine, Kagawa University, Japan

${ }^{c}$ Department of Anatomy and Neurobiology, Faculty of Medicine, Kagawa University, Japan

${ }^{\mathrm{d}}$ Corresponding author: Mostofa Jamal, Department of Forensic Medicine, Faculty of Medicine, Kagawa University, 1750-1, Ikenobe, Miki, Kita, Kagawa 761-0793, Japan. Email: jamal@kms.ac.jp

doi: http://dx.doi.org/10.4021/jnr217e
Keywords: Neurotrophin genes and receptors; Nicotine; Frontal cortex; Hippocampus; ApoE-knockout mice

\section{Introduction}

The neurotrophin family includes nerve growth factor (NGF), brain-derived neurotrophic factor (BDNF), neurotrophin-3, neurotrophin-4/5, and neurotrophin-6 [1, 2]. Neurotrophins exert their effects through the binding and activation of the tyrosine kinase (Trk) family of receptors at the axon terminals of innervating neurons. Nicotine interacts with nicotinic acetylcholine receptors (nAChRs) to produce neuroprotective as well as neurotoxic effects on the animal brain $[3,4]$. This neuroprotection could be mediated through nicotinic regulation of the expression of NGF, BDNF, and their receptors $[5,6]$. It has been shown that NGF and BDNF play important roles in cognitive ability and in maintenance of cholinergic neurons of the basal forebrain (BF) [7, 8]. Survival of $\mathrm{BF}$ cholinergic neurons depends on the binding of NGF and BDNF, which are synthesized and secreted by cells in the cerebral cortex and hippocampus, with their receptors, which are produced within BF cholinergic neurons. Thus, the neurotrophin system is an important potential target of nicotine in the brain.

Apolipoprotein E (ApoE) is a key transporter of cholesterol and phospholipids required for membrane synthesis and nerve growth [9]. ApoE binds ciliary neurotrophic factor (CNTF) and potentiates the survival-promoting activity of CNTF for hippocampal neurons [10]. The three major isoforms of ApoE exit in human (E2, E3 and E4). Nicotine has been shown to produce a larger cognitive benefit in young-adult ApoE4 carriers [11]. These results suggest that the ApoE may influence behavior and cognitive functions, including learning and memory. To support this hypothesis, a number of studies have been carried out in ApoE-knockout (ApoE-KO) mice, and their results have revealed a greater attenuation of long-term potentiation (LTP) compared with WT mice $[12,13]$. Impaired LTP in ApoE-KO mice might be associated with alterations of synaptic plasticity in the hippocampus [14]. Moreover, a significant deficit of cholinergic 
function and memory has also been observed in ApoE-KO mice [15]. Thus, ApoE-KO mice that are deficient in ApoE have previously been used to study the role of ApoE in the function of distinct neuronal systems and cognition [16].

Several studies have detected nicotine-associated increases in the mRNA and protein expression of NGF, BDNF and TrkA and TrkB receptors in multiple brain regions [5, $17,18]$. Most of these studies have reported chronic nicotine effects on neurotrophins in animal. Very few studies have focused on the acute effects of nicotine on the BDNF mRNA level in the rat brain [19]. Given the links between nicotine and the neurotrophin system, we examined the effects of acute nicotine on mRNA expression of the neurotrophin ligand and receptor systems in the brain regions linked to cognition. We also evaluated whether these changes correlate with strain differences. To accomplish these aims, real-time PCR was used to measure mRNA expression in the frontal cortex and hippocampus of ApoE-KO and wild-type (WT) mice $30 \mathrm{~min}$ after the intraperitoneal (i.p.) administration of different doses of nicotine $(0.1-1.0 \mathrm{mg} / \mathrm{kg})$.

\section{Materials and Methods}

\section{Animals}

All animal experiments were approved by the Kagawa University Animal Investigation Committee. All mice used were of the C57BL/6 genetic background. Breeding pairs for ApoE-KO mice were used as described previously [20]. The male WT mice used as the controls were purchased from CLEA Japan (Tokyo, Japan). All experiments were conducted with mice that were $10-12$ weeks of age and weighed 24 - 28 g. All animals were housed under controlled temperature $\left(21 \pm 3{ }^{\circ} \mathrm{C}\right)$, humidity (50-70\%), and light (12-h lightdark cycle) conditions.

\section{Experimental groups}

Twenty-eight male mice from each strain (ApoE-KO and WT) were divided into four groups ( $n=7$ per group) and received one of the following treatments: (a) saline, (b) 0.1 $\mathrm{mg} / \mathrm{kg}$ of nicotine, (c) $0.5 \mathrm{mg} / \mathrm{kg}$ of nicotine, and (d) $1.0 \mathrm{mg} /$ $\mathrm{kg}$ of nicotine. Nicotine hydrogen tartrate (Sigma-Aldrich) was dissolved in $0.9 \%$ saline, and all injections were given in a volume of $10 \mathrm{~mL} / \mathrm{kg}$ (free base of nicotine tartrate). The brain tissues were collected $30 \mathrm{~min}$ after the mice received an i.p. injection of nicotine or saline.

\section{Brain tissue}

The mice were anesthetized with diethyl ether and then decapitated. Their brains were quickly removed and washed in ice-cold $\left(4^{\circ} \mathrm{C}\right)$ artificial cerebrospinal fluid (aCSF) saturated with carbogen gas $\left(95 \% \mathrm{O}_{2}\right.$ and $\left.5 \% \mathrm{CO}_{2}\right)$. The aCSF consisted of $124 \mathrm{mM} \mathrm{NaCl}, 21 \mathrm{mM} \mathrm{NaHCO}, 3 \mathrm{mM} \mathrm{KCl}, 1.25 \mathrm{mM}$ $\mathrm{NaH}_{2} \mathrm{PO}_{4}, 1.6 \mathrm{mM} \mathrm{CaCl}_{2}, 1.8 \mathrm{mM} \mathrm{MgSO}_{4}$, and $10 \mathrm{mM}$ glucose at $\mathrm{pH}$ 7.4. The frontal cortex was collected on ice and then frozen at $-70{ }^{\circ} \mathrm{C}$ until RNA isolation was performed.

\section{Hippocampal slice}

Coronal brain slices (500 $\mu \mathrm{m}$ thick) through the hippocampus were cut with a microslicer (DTK-1000, Japan) while immersed in the ice-cold aCSF. The slice was then dipped immediately in an oxygenated aCSF solution. Using a standard microscope for visualization, the hippocampus was removed and immediately transferred to a tube containing 0.5 $\mathrm{mL}$ of Trizol (Invitrogen). The tissue samples were then homogenized with Polytron (PT 2500E), and an additional 0.5 $\mathrm{mL}$ of Trizol was added for a total sample volume of $1.0 \mathrm{~mL}$.

\section{Real-time PCR}

A 5- $\mu$ g aliquot of total RNA from each tissue sample was used as a template for reverse transcription and was primed with $1 \mu \mathrm{L}$ of oligo (dT)18 primer (Clontech, Japan). An appropriate amount of DEPC was added to a final volume of $13.5 \mu \mathrm{L}$. The synthesis reaction contained $4 \mu \mathrm{L}$ of $5 \mathrm{X}$ reaction buffer, $1 \mu \mathrm{L}$ of $10 \mathrm{mM}$ dNTP-mix, $0.5 \mu \mathrm{L}$ of $40 \mathrm{U} / \mu \mathrm{L}$ recombinant RNase inhibitor, and $1 \mu \mathrm{L}$ of $200 \mathrm{U} / \mu \mathrm{L}$ MMLV reverse transcriptase in a final volume of $20 \mu \mathrm{L}$. The total RNA was pre-incubated for $2 \mathrm{~min}$ at $70{ }^{\circ} \mathrm{C}$ prior to cDNA synthesis, and the reverse transcription reaction was performed for $60 \mathrm{~min}$ at $42{ }^{\circ} \mathrm{C}$ followed by $5 \mathrm{~min}$ at $94^{\circ} \mathrm{C}$. The sequences for the primers are given in Table 1. A SYBR Green master mix (Roche, USA) was used to measure the accumulation of PCR product for each reaction. The PCR amplification protocol consisted of one cycle at $95{ }^{\circ} \mathrm{C}$ for $10 \mathrm{~min}$, followed by 45 cycles at the following parameters: $40 \mathrm{~s}$ of denaturation at $95^{\circ} \mathrm{C}, 40 \mathrm{~s}$ of annealing at $60^{\circ} \mathrm{C}$ and $1 \mathrm{~min} 20 \mathrm{~s}$ of extension at $72^{\circ} \mathrm{C}$ using the ABI Prism 7700 Sequence Detection System driven by the ABI prism SDS version 9.1 software (Applied Biosystems). The relative expression of the genes of interest was normalized to the mean of the $\beta$-actin (internal control) mRNA that was amplified in different wells on the same plate.

\section{Statistics}

All values are expressed as the means \pm standard error of the mean (SE); values of $\mathrm{P}<0.05$ were considered significant. The data were analyzed with the SigmaStat (Systat, version 3.0) software using a one-way analysis of variance (ANOVA). Post-hoc tests were performed, where appropriate. The student's t-test was used to assess significant differences in neurotrophins and their receptors expression between the two strains. 
Table 1. Primer Sequences Used for mRNA Quantification by Real-Time PCR

\begin{tabular}{|c|c|c|c|c|}
\hline Gene & Primers & Base pairs & Gene accession number & Position \\
\hline \multirow[t]{2}{*}{ NGF } & $5^{\prime}$-CAGACCCGGAACATCACTGTA-3' & 134 & NM_013609 & $5^{\prime}: 628-605$ \\
\hline & $5^{\prime}$-CCATGGGCCTGGAAGTCTAG-3' & & & $5^{\prime}: 494-513$ \\
\hline \multirow[t]{2}{*}{$\mathrm{BDNF}$} & $5^{\prime}$-GGTATCCAAAGGCCAACTGA-3' & 182 & NM_007540 & $5^{\prime}: 1180-1199$ \\
\hline & $5^{\prime}$-CTTATGAATCGCCAGCCAAT-3' & & & $5^{\prime}: 1362-1343$ \\
\hline \multirow[t]{2}{*}{ TrkA } & $5^{\prime}$-AGAGTGGCCTCCGCTTTGT-3' & 80 & NM_002529 & $5^{\prime}: 355-373$ \\
\hline & $5^{\prime}$-CGCATTGGAGGACAGATTCA-3' & & & $5^{\prime}: 434-415$ \\
\hline \multirow[t]{2}{*}{ TrkB } & $5^{\prime}$-CGCCCTGTGAGCTGAACTCTG-3' & 174 & NM_008745 & $5^{\prime}: 2256-2232$ \\
\hline & $5^{\prime}$-CTGCTTCTCAGCTGCCTGACC-3' & & & $5^{\prime}: 2082-2102$ \\
\hline \multirow[t]{2}{*}{$\beta$-action } & $5^{\prime}$-AGCCATGTACGTAGCCATCC-3' & 250 & NM_007393 & $5^{\prime}: 720-700$ \\
\hline & $5^{\prime}$-TTTGATGTCACGCACGATTT-3' & & & $5^{\prime}: 470-489$ \\
\hline
\end{tabular}

\section{Results}

Fig. 1 shows the neurotrophins and their receptors mRNA expression levels in the saline and the nicotine $(0.1-1.0 \mathrm{mg} / \mathrm{kg})$ groups for the frontal cortex. In ApoE-KO mice, a significant main effect of treatment for the expression levels of NGF ( $\mathrm{df}$ $3,27 ; \mathrm{F}=3.994 ; \mathrm{P}<0.05)$ and $\mathrm{BDNF}(\mathrm{df} 3,27 ; \mathrm{F}=4.491 ; \mathrm{P}<$ 0.05 ) was detected. Treatment with $0.1 \mathrm{mg} / \mathrm{kg}$ of nicotine pro- duced a remarkable decrease in the levels of NGF $(\mathrm{P}<0.05)$ and BDNF $(\mathrm{P}<0.01)$ compared with saline (Fig. 2A, B). For TrkA and TrkB, there was no significant effect of any of the doses of nicotine on their mRNA levels.

In WT mice, a significant main effect of treatment for NGF (df 3, 27; $\mathrm{F}=3.665 ; \mathrm{P}<0.05$ ) and TrkA (df 3, 27; $\mathrm{F}=9.881$; $\mathrm{P}<0.001$ ) was detected. Treatment with $0.1 \mathrm{mg} / \mathrm{kg}$ of nicotine produced a remarkable decrease in the levels of NGF $(\mathrm{P}<0.05)$
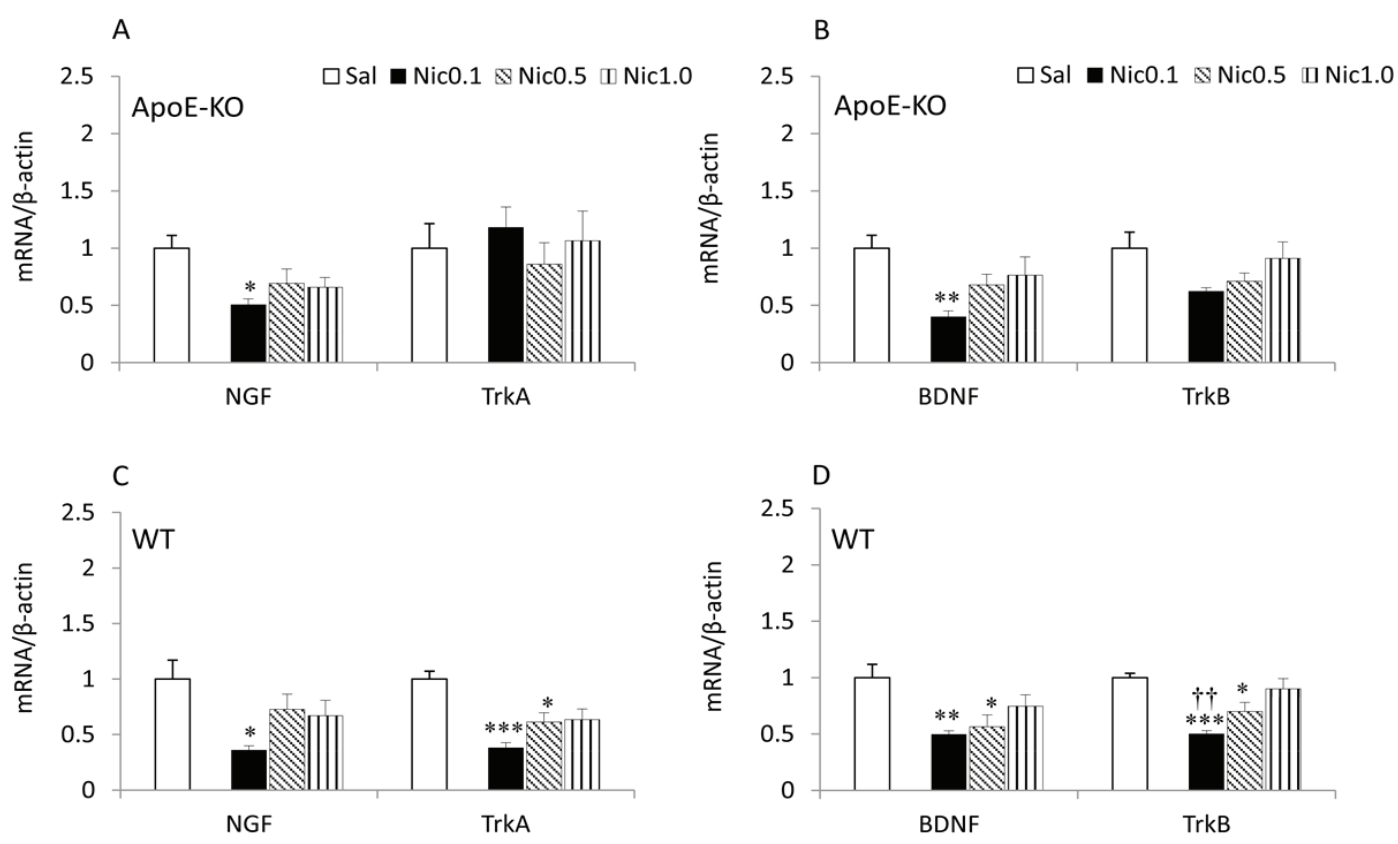

Figure 1. NGF, BDNF and their receptors mRNA expression in the frontal cortex of ApoE-KO (A, B) and WT (C, D) mice. Data represent the means $\pm S E(n=7)$. ${ }^{*} P<0.05$, ${ }^{* *} P<0.01$ and ${ }^{* *} P<0.001$ versus $S a l$, and $+\dagger P<0.01$ versus Nic 1.0 $\mathrm{mg} / \mathrm{kg}$. Sal, saline; Nic, nicotine 

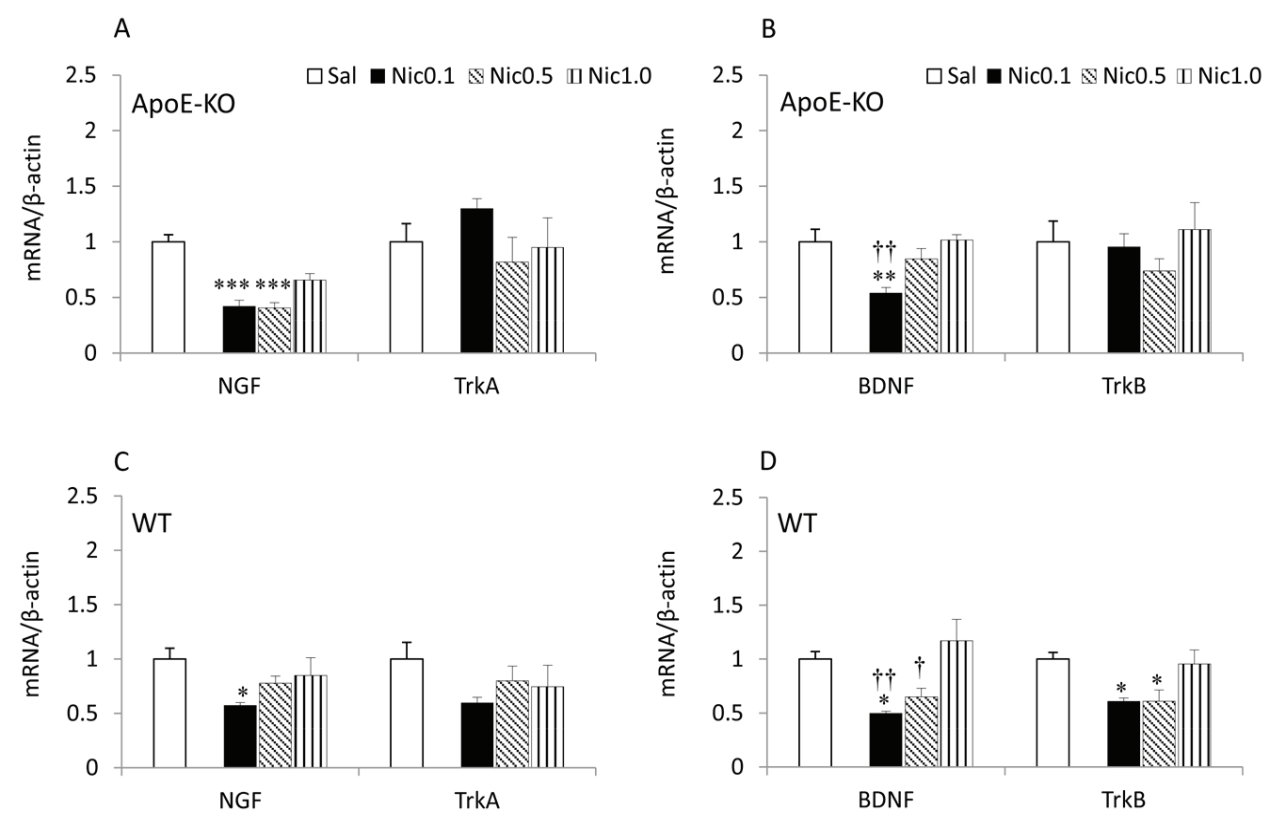

Figure 2. NGF, BDNF and their receptors mRNA expression in the hippocampus of ApoE-KO $(A, B)$ and WT (C, D) mice. Data represent the means $\pm S E(n=7)$. ${ }^{*} P<0.05$, ${ }^{* *} P<0.01$ and ${ }^{* * *} P<0.001$ versus Sal, and $\dagger P<$ $0.05, \mathrm{\dagger} \uparrow \mathrm{P}<0.01$ versus Nic $1.0 \mathrm{mg} / \mathrm{kg}$. Sal, saline; Nic, nicotine

and treatment with $0.1(\mathrm{P}<0.001)$ and $0.5(\mathrm{P}<0.05) \mathrm{mg} / \mathrm{kg}$ of nicotine resulted in a significant decrease in the levels of TrkA compared with saline (Fig. 2C). The ANOVA revealed a significant main effect of treatment for BDNF (df 3, 27; F = 4.940; $\mathrm{P}$ $<0.01)$ and TrkB (df 3, 27; F = 10.246; $\mathrm{P}<0.001)$. Treatment with $0.1(\mathrm{P}<0.01)$ and $0.5(\mathrm{P}<0.05) \mathrm{mg} / \mathrm{kg}$ of nicotine resulted in a significant decrease in the levels of BDNF and treatment with $0.1(\mathrm{P}<0.001)$ and $0.5(\mathrm{P}<0.05) \mathrm{mg} / \mathrm{kg}$ of nicotine resulted in a significant decrease in the levels of TrkB compared with saline (Fig. 2D). The results also showed that treatment with 0.1 $\mathrm{mg} / \mathrm{kg}$ of nicotine $(\mathrm{P}<0.01)$ caused a significant decrease in the levels of TrkB compared to $1.0 \mathrm{mg} / \mathrm{kg}$ nicotine.

Fig. 2 shows the neurotrophins and their receptors mRNA expression levels in the saline and the nicotine $(0.1-1.0 \mathrm{mg} / \mathrm{kg})$ groups for the hippocampus. In ApoE-KO mice, a significant main effect of treatment for the expression levels of NGF ( $\mathrm{df}$ $3,27 ; \mathrm{F}=20.710 ; \mathrm{P}<0.001)$ and $\mathrm{BDNF}(\mathrm{df} 3,27 ; \mathrm{F}=6.824$;
$\mathrm{P}<0.01$ ) was detected. Treatment with 0.1 and $0.5 \mathrm{mg} / \mathrm{kg}$ of nicotine produced a significant decrease in the levels of NGF (P $<0.001$ ) and treatment with $0.1 \mathrm{mg} / \mathrm{kg}$ of nicotine produced a significant decrease in the levels of BDNF $(\mathrm{P}<0.01)$ compared with saline (Fig. 3A, B). The results also revealed that administration of $0.1(\mathrm{P}<0.01) \mathrm{mg} / \mathrm{kg}$ of nicotine resulted in a significant decrease in the BDNF mRNA levels compared with 1.0 $\mathrm{mg} / \mathrm{kg}$ nicotine. For TrkA and TrkB, the ANOVA revealed no significant effect of any of the doses of nicotine on their mRNA levels.

In WT mice, a significant main effect of treatment for NGF (df 3, 27; F = 3.757; P < 0.05) was detected. Treatment with 0.1 $\mathrm{mg} / \mathrm{kg}$ of nicotine resulted in a significant decrease in the levels of NGF mRNA $(\mathrm{P}<0.05)$ compared with saline (Fig. 3C). No significant effect of any of the doses of nicotine on TrkA was found. The ANOVA revealed a significant main effect of treatment for BDNF (df 3, 27; F = 6.626; $\mathrm{P}<0.01)$ and TrkB (df 3 ,
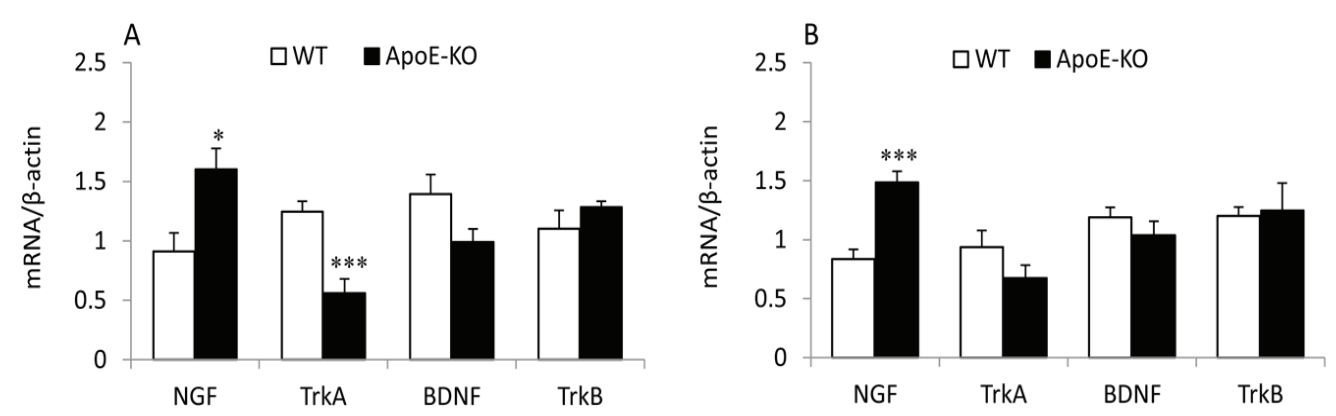

Figure 3. Strain effects on the mRNA expression levels of NGF, BDNF and their receptors in the saline group of frontal cortex (A) and hippocampus (B). ${ }^{*} \mathrm{P}<0.05$ and ${ }^{* * *} \mathrm{P}<0.001$ for the difference between ApoE-KO and WT mice. 
$27 ; \mathrm{F}=4.911 ; \mathrm{P}<0.01)$. Treatment with $0.1 \mathrm{mg} / \mathrm{kg}$ of nicotine resulted in a significant decrease in the levels of BDNF $(\mathrm{P}<$ 0.05 ) and treatment with 0.1 and $0.5 \mathrm{mg} / \mathrm{kg}$ of nicotine caused a significant decrease in the levels of TrkB mRNA $(\mathrm{P}<0.05)$ compared with saline. The results also revealed that administration of $0.1(\mathrm{P}<0.01)$ and $0.5(\mathrm{P}<0.05) \mathrm{mg} / \mathrm{kg}$ of nicotine resulted in a significant decrease in the BDNF mRNA levels compared with $1.0 \mathrm{mg} / \mathrm{kg}$ nicotine.

Fig. 3 shows a comparison of mRNA expression of neurotrophins and their receptors between two strains of mice. ApoEKO mice exhibited a significantly higher NGF mRNA expression than WT mice in both the frontal cortex $(\mathrm{P}<0.05)$ and the hippocampus $(\mathrm{P}<0.001)$. In contrast, TrkA mRNA expression was found to be significantly lower $(\mathrm{P}<0.001)$ in the frontal cortex of ApoE-KO mice than WT mice, with no effects in the hippocampus. The BDNF and TrkB mRNA levels remained unchanged either in the brain regions studied.

\section{Discussion}

The most notable effect of nicotine on the frontal cortex and hippocampus was that the NGF and BDNF mRNA expression levels were decreased in both strains of mice (Fig. 1, 2). Interestingly, this effect was dependent on low-intermediate doses $(0.1$ and $0.5 \mathrm{mg} / \mathrm{kg})$ of nicotine, whereas at $1.0 \mathrm{mg} / \mathrm{kg}$, the effect of nicotine was not seen. Nicotine also decreased TrkA and TrkB receptor mRNA levels in WT mice (Fig. 1C, $\mathrm{D}$ and 2D), but not in ApoE mice, whereas 0.1 and $0.5 \mathrm{mg} /$ $\mathrm{kg}$ of nicotine caused a decrease in the mRNA levels of TrkA receptor in the frontal cortex and TrkB in both brain regions.

Here, we administered the ApoE-KO and WT mice models an i.p. injection of nicotine to investigate the effects of nicotine on the mRNA levels of NGF, BDNF and their receptors in the frontal cortex and hippocampus at $30 \mathrm{~min}$ after administration. Nicotine is able to get into the brain by traveling through the blood-brain barrier and begins to rise following administration [21]. It reaches maximum levels in the rat brain over the first 60-min post-subcutaneous administration, followed by a significant decrease [22].

The present results suggest that exposure of mice to low-moderate doses of nicotine can cause the frontal cortex and hippocampus to down-regulate the mRNA expression of NGF and BDNF. This finding appears to agree in part with the results of Kenny et al (2000) [19] where acute nicotine exposure significantly decreased the BDNF mRNA levels in the rat hippocampus $2 \mathrm{~h}$ and $24 \mathrm{~h}$ after administration. In addition, another study showed a decrease of NGF in the hippocampus of aged female rats with chronic nicotine $(0.3 \mathrm{mg} /$ $\mathrm{kg} /$ day) treatment [23]. Taken together, these finding lend support to our hypothesis that acute nicotine with a certain low concentration can reduce NGF and BDNF mRNA levels in the mouse brain.

We further demonstrated a significant decrease in TrkA
mRNA expression in the frontal cortex of WT mice, whereas TrkB levels were decreased in both the frontal cortex and hippocampus. Indeed, this effect was limited to low and intermediate doses $(0.1$ and $0.5 \mathrm{mg} / \mathrm{kg})$ of nicotine. The reason for the lack of a similar decrease in TrkA mRNA levels in the hippocampus is unclear at present; nicotine induced a decreasing trend although it was not statistically significant. ApoE-KO mice did not show a significant change in mRNA levels of TrK receptors with any of the doses of nicotine given in either brain region. The mechanism underlying this difference is not clear, but our recent study provides evidence that ApoE deficiency may influence the efficacy of nicotine [14]. Thus, it is conceivable that nicotine induced no effects on Trk receptor mRNA in ApoE-mice due to a link between nicotine dose and TrK receptor sensitivity.

Numerous studies have demonstrated that NGF and BDNF are produced in the cerebral cortex and hippocampus, and retrograde transportation to $\mathrm{BF}$ cholinergic neurons cell bodies is indeed responsible for their trophic effect [24-26]. Our finding of a decrease in NGF and BDNF mRNA levels after low-intermediate doses of nicotine may suggest that acute nicotine administration may impair retrograde transport. Although our results demonstrate a significant decrease in most indexes of NGF and BDNF mRNA levels, most likely due to the direct effects of nicotine, it appears that the overall effect of nicotine exposure is more complicated. Further studies are needed to elucidate the precise molecular mechanism(s).

It has been shown that a high dose $(\geq 1 \mathrm{mM})$ of nicotine may induce neurotoxicity and stimulate oxidative stress, while a reasonably low concentration $(10 \mu \mathrm{M})$ may act as an antioxidant and play an important neuroprotective effect [3]. These opposite effects are related to differences in doses of the drug and administration schedules [27]. Nicotine produced different results in our study: decreased neurotrophin levels at low and intermittent doses $(0.1$ and $0.5 \mathrm{mg} / \mathrm{kg})$ and no effects at a higher dose $(1.0 \mathrm{mg} / \mathrm{kg})$ in both strains of mice. The individual differences in response to nicotine are not surprising [28] because different neurotransmitters and different brain regions mediate different effects of nicotine. Our findings raise the possibility that differences in nicotine dose and time of injection influence the effects of nicotine on neurotrophins.

Strain effects on the mRNA levels of neurotrophins and their receptors were measured among the saline groups of mice in this study (Fig. 3A, B). ApoE-KO mice showed a distinctly higher level of NGF mRNA expression in both brain regions versus WT mice. On the contrary, TrkA mRNA levels were lower in the frontal cortex of ApoE-KO mice versus WT mice. These findings indicate that the ApoE deficiency may cause a differential response in the various neurotrophin ligand/receptor systems in the mouse brain. The increase in NGF mRNA levels in the brain is consistent with previous reports where NGF protein levels were shown to 
be increased in the brain of $\mathrm{AD}$ [29]. The observed lack of change in BDNF and TrkB mRNA levels in the hippocampus of ApoE-KO and WT mice is in line with a previous report [30].

Several studies have demonstrated a significant decrease of cholinergic function and memory in ApoE-KO mice [15, $31,32]$. It has been postulated that cholinergic deficit correlates inversely with NGF-like activity $[33,34]$. The rationale behind this prediction is that the loss of cholinergic fibers leads to reduced choline acetyltransferase activity along with increased levels of NGF. Thus, NGF might be of importance in the stimulation of compensatory changes [33]. Therefore, our finding of a high NGF mRNA expression in the brain of ApoE-KO mice is most likely due to a reduction of central cholinergic function.

\section{Conclusion}

Acute treatment of mice with nicotine causes a decrease in the expression of NGF and BDNF mRNA in the studied brain. Nicotine also decreased TrkA and TrkB receptors mRNA levels in the brain of WT, with no changes in ApoE mice. Interestingly, all of these effects were limited to low-intermediate doses $(0.1$ and $0.5 \mathrm{mg} / \mathrm{kg})$ of nicotine. All together, we hypothesize that acute administration of a low concentration of nicotine may induce down-regulation of mRNA expression of NGF, BDNF and their receptors in the mouse brain. Vehicle-treated ApoE-KO mice exhibited elevated NGF and lowered TrkA levels in comparison to WT mice. This enhancement of neurotrophin signaling seen among the ApoE-KO mice may explain their seeming resistance to the down-regulating effects of acute nicotine treatment, which attribute to reduce cholinergic activity reported elsewhere, a phenomenon which deserves further investigation.

\section{Acknowledgement}

This work was supported in part by the Grant-in-Aid for Scientific Research (Grand No (c) 22590636, 20590681) from the Ministry of Education, Culture, Sports, Science and Technology, Japan. We thank Ken-ichi Ohta, department of Anatomy and Neurobiology of Kagawa University for helping statistical analysis.

\section{References}

1. Allen SJ, Dawbarn D. Clinical relevance of the neurotrophins and their receptors. Clin Sci (Lond). 2006;110(2):175-191.

2. Ip NY, Yancopoulos GD. Neurotrophic factors and their receptors. Prog Brain Res. 1995;105(189-195.

3. Guan ZZ, Yu WF, Nordberg A. Dual effects of nicotine on oxidative stress and neuroprotection in PC12 cells. Neurochem Int. 2003;43(3):243-249.

4. Huang LZ, Parameswaran N, Bordia T, Michael McIntosh J, Quik M. Nicotine is neuroprotective when administered before but not after nigrostriatal damage in rats and monkeys. J Neurochem. 2009;109(3):826-837.

5. Czubak A, Nowakowska E, Kus K, Burda K, Metelska J, Baer-Dubowska W, Cichocki M. Influences of chronic venlafaxine, olanzapine and nicotine on the hippocampal and cortical concentrations of brain-derived neurotrophic factor (BDNF). Pharmacol Rep. 2009;61(6):10171023.

6. Jonnala RR, Terry AV, Jr., Buccafusco JJ. Nicotine increases the expression of high affinity nerve growth factor receptors in both in vitro and in vivo. Life Sci. 2002;70(13):1543-1554

7. Allard S, Leon WC, Pakavathkumar P, Bruno MA, Ribeiro-da-Silva A, Cuello AC. Impact of the NGF maturation and degradation pathway on the cortical cholinergic system phenotype. J Neurosci. 2012;32(6):2002-2012.

8. Backman C, Rose GM, Hoffer BJ, Henry MA, Bartus RT, Friden P, Granholm AC. Systemic administration of a nerve growth factor conjugate reverses age-related cognitive dysfunction and prevents cholinergic neuron atrophy. J Neurosci. 1996;16(17):5437-5442.

9. Raffai RL, Weisgraber KH. Cholesterol: from heart attacks to Alzheimer's disease. J Lipid Res. 2003;44(8):1423-1430.

10. Gutman CR, Strittmatter WJ, Weisgraber KH, Matthew WD. Apolipoprotein E binds to and potentiates the biological activity of ciliary neurotrophic factor. J Neurosci. 1997;17(16):6114-6121.

11. Marchant NL, King SL, Tabet N, Rusted JM. Positive effects of cholinergic stimulation favor young APOE epsilon4 carriers. Neuropsychopharmacology. 2010;35(5):1090-1096.

12. Krzywkowski P, Ghribi O, Gagne J, Chabot C, Kar S, Rochford J, Massicotte G, et al. Cholinergic systems and long-term potentiation in memory-impaired apolipoprotein E-deficient mice. Neuroscience. 1999;92(4):12731286.

13. Valastro B, Ghribi O, Poirier J, Krzywkowski P, Massicotte G. AMPA receptor regulation and LTP in the hippocampus of young and aged apolipoprotein E-deficient mice. Neurobiol Aging. 2001;22(1):9-15.

14. Krugers HJ, Mulder M, Korf J, Havekes L, de Kloet ER, Joels M. Altered synaptic plasticity in hippocampal CA1 area of apolipoprotein E deficient mice. Neuroreport. 1997;8(11):2505-2510.

15. Gordon I, Grauer E, Genis I, Sehayek E, Michaelson DM. Memory deficits and cholinergic impairments in apolipoprotein E-deficient mice. Neurosci Lett. 1995;199(1):1-4.

16. Masliah E, Mallory M, Ge N, Alford M, Veinbergs I, Ros- 
es AD. Neurodegeneration in the central nervous system of apoE-deficient mice. Exp Neurol. 1995;136(2):107122.

17. Formaggio E, Fazzini F, Dalfini AC, Di Chio M, Cantu C, Decimo I, Fiorini Z, et al. Nicotine increases the expression of neurotrophin receptor tyrosine kinase receptor A in basal forebrain cholinergic neurons. Neuroscience. 2010;166(2):580-589.

18. French SJ, Humby T, Horner CH, Sofroniew MV, Rattray M. Hippocampal neurotrophin and trk receptor mRNA levels are altered by local administration of nicotine, carbachol and pilocarpine. Brain Res Mol Brain Res. 1999;67(1):124-136.

19. Kenny PJ, File SE, Rattray M. Acute nicotine decreases, and chronic nicotine increases the expression of brainderived neurotrophic factor mRNA in rat hippocampus. Brain Res Mol Brain Res. 2000;85(1-2):234-238.

20. Sultana R, Ameno K, Jamal M, Miki T, Tanaka N, Ono J, Kinoshita $\mathrm{H}$, et al. Low-dose nicotine facilitates spatial memory in ApoE-knockout mice in the radial arm maze. Neurol Sci. 2013;34(6):891-897.

21. Lockman PR, McAfee G, Geldenhuys WJ, Van der Schyf CJ, Abbruscato TJ, Allen DD. Brain uptake kinetics of nicotine and cotinine after chronic nicotine exposure. J Pharmacol Exp Ther. 2005;314(2):636-642.

22. Crooks PA, Li M, Dwoskin LP. Metabolites of nicotine in rat brain after peripheral nicotine administration. Cotinine, nornicotine, and norcotinine. Drug Metab Dispos. 1997;25(1):47-54.

23. French KL, Granholm AC, Moore AB, Nelson ME, Bimonte-Nelson HA. Chronic nicotine improves working and reference memory performance and reduces hippocampal NGF in aged female rats. Behav Brain Res. 2006;169(2):256-262.

24. Hefti F. Nerve growth factor promotes survival of septal cholinergic neurons after fimbrial transections. J Neurosci. 1986;6(8):2155-2162.

25. Mufson EJ, Kroin JS, Sendera TJ, Sobreviela T. Distribution and retrograde transport of trophic factors in the central nervous system: functional implications for the treatment of neurodegenerative diseases. Prog Neurobiol. 1999;57(4):451-484.
26. Schindowski K, Belarbi K, Buee L. Neurotrophic factors in Alzheimer's disease: role of axonal transport. Genes Brain Behav. 2008;7 Suppl 1(43-56.

27. Ferger B, Spratt C, Earl CD, Teismann P, Oertel WH, Kuschinsky K. Effects of nicotine on hydroxyl free radical formation in vitro and on MPTP-induced neurotoxicity in vivo. Naunyn Schmiedebergs Arch Pharmacol. 1998;358(3):351-359.

28. Nesil T, Kanit L, Collins AC, Pogun S. Individual differences in oral nicotine intake in rats. Neuropharmacology. 2011;61(1-2):189-201.

29. Hock C, Heese K, Hulette C, Rosenberg C, Otten U. Region-specific neurotrophin imbalances in Alzheimer disease: decreased levels of brain-derived neurotrophic factor and increased levels of nerve growth factor in hippocampus and cortical areas. Arch Neurol. 2000;57(6):846-851.

30. Wang ZY, Miki T, Ding Y, Wang SJ, Gao YH, Wang XL, Wang YH, et al. A high cholesterol diet given to apolipoprotein E-knockout mice has a differential effect on the various neurotrophin systems in the hippocampus. Metab Brain Dis. 2011;26(3):185-194.

31. Jamal M, Ameno K, Miki T, Tanaka N, Ono J, Shirakami G, Sultana R, et al. High ethanol and acetaldehyde impair spatial memory in mouse models: opposite effects of aldehyde dehydrogenase 2 and apolipoprotein $\mathrm{E}$ on memory. Pharmacol Biochem Behav. 2012;101(3):443449.

32. Siegel JA, Benice TS, Van Meer P, Park BS, Raber J. Acetylcholine receptor and behavioral deficits in mice lacking apolipoprotein E. Neurobiol Aging. 2011;32(1):7584.

33. Hellweg R, Humpel C, Lowe A, Hortnagl H. Moderate lesion of the rat cholinergic septohippocampal pathway increases hippocampal nerve growth factor synthesis: evidence for long-term compensatory changes? Brain Res Mol Brain Res. 1997;45(1):177-181.

34. Scott SA, Mufson EJ, Weingartner JA, Skau KA, Crutcher KA. Nerve growth factor in Alzheimer's disease: increased levels throughout the brain coupled with declines in nucleus basalis. J Neurosci. 1995;15(9):62136221. 